\title{
MUNICIPAL LAKE GOVERNANCE DEVELOPMENTS IN LATVIA: TOWARDS COMPLEX APPROACH MANAGEMENT PRACTICE
}

\author{
Karlis Aleksandrs Konkovs ${ }^{1}$, MSc.Env.; Raimonds Ernsteins ${ }^{2}$, Dr.habil.paed./ Prof.
}

1, 2Environmental Science Department, University of Latvia, Riga, Latvia

\begin{abstract}
Latvia has a significant number of lakes, even eventually more as 10000 as they never been fully accounted, but just comparatively small number are subject to lake governance, since the entire national lake governance system is still under development and currently mostly municipalities themselves are step-wise developing and realising lake management plans, but municipal capacities vary significantly. According to EU Water framework directive, there are four river basin management systems established in Latvia, having related water and risk management documents in place, as well as, in the past decade, there have been both national and regional level planning guidelines developed for lake and river waterbodies management, but all mentioned has been not yet utilized in local practice, having some legal responsibilities' and admin capacities' deficiencies. Despite this, there has been seen slow improvement of the water quality and socio-economic usage of lakes, but more in the lake management practice is to be done, accounting also for climate change.

The goal of this research was to study the municipal level lake management practice developments, applying general research-and-development (R\&D) framework approach and researching particularly the status and development trends of the three governance's dimensions' employment - governance content by socio-ecological system (SES) approach, governance segments as for main stakeholders' involvement and participation, as well as, the set of governance instruments, especially, institutional/administrative ones. There were chosen pilot municipalities, having diverse and successful lake management approaches utilised, and, for the first study stage, document analysis and semi-structured interviews with related municipal specialists were done, using case study research (CSR) methodology application.

There were recognized five lake management approaches, even in most municipalities in Latvia, particularly in rural ones, lake management is traditionally done by the scarce municipal territory administrative units and Utilities departments/services, and, only limited number of municipalities, also particularly studied, have developed and are employing for lake management also nature resource/environmental departments, while only in few municipalities there are established special municipal lake management agencies. Promising looks NGO sector management approach used by some municipalities, both top-down either bottom-up establishment chosen to apply, but as most perspective could be recognised complex approach (cross-sector) management practice, where most or all above mentioned approaches are combined and complementary supporting each other, within particular municipality. All studied municipalities possess certain lake management success stories, to be studied further in very detail, however, in general, there is to be seen still limited understanding and utilisation of the SES approach, also still potential of various stakeholder's involvement and pro-active development of all complementary governance instruments, even many of instruments are available in studied municipalities, but lake communication instruments (information, education/training, participation and lakefriendly behaviour) are mostly underdeveloped.
\end{abstract}

Keywords: lake governance, management approaches, governance instruments, segments and content. JEL code: Q01, Q25, Q56, R58

\section{Introduction}

Lake governance in Latvia is an important issue, as some municipalities in the country are to some extent dependent on lakes and rivers as an important socio-ecological resource system. However, lakes in Latvia, just like in other Northern European countries, are subject to eutrophication (Lakes of Latvia 2015) and, furthermore, lakes in Latvia also suffer from pollution with biogenic elements due to wastewater inflow from smaller settlements, and surface runoff from agricultural areas and forests. Infrastructure issues are also common, as smaller lakes may not have access roads, while larger lakes often are subject to irregular studies and infrastructure improvements since rural municipalities having limited resources. Latvia's lake

1 Karlis Aleksandrs Konkovs <kk13265@edu.lu.lv> 
governance has been, until recently, rarely studied by researchers, with most research done about lakes in Latvia being about environmental quality and rare species of plants and animals (Blenckner et al., 2009). The state owns the public waters, to be used by all Latvia residents as is established by Civil Law - Latvia have eventually more as 10000 lakes as never been fully accounted, but comparatively small number of the most important ones are public lakes (207) and private lakes with fishing rights belonging to the state (208) and all other are private lakes - altogether, there are 2256 lakes, covering above 1 ha, making lake covered territory around 100000 ha, what covers $1.5 \%$ of Latvia territory. Just 16 lakes are above 10 km², but those lakes cover almost half the territory of all lakes. Even lake quality has been slowly improving; according to OCED and European Commission statistics, lakes in Latvia are below average in Europe regarding their environmental quality.

According to the European committee and OCED reports, Latvian lake governance and water resources management is in permanent step-wise developing, including lake and river monitoring yet are partly developed as all depending on environmental administrative capacities and capabilities compare to the number of lakes and other waterbodies. National environmental governance is aware about situation in general and, besides main legislation and planning documents, has developed also ministerial guidelines for governance of rivers and lakes, and, also special guidelines have been done by several planning regions in Latvia. There is improved lake and river monitoring and lake governance in protected areas (Zacharias et al., 2020). Most of the practical improvements are done by the municipalities themselves, particularly during last year's actively developing lake governance plans and as possible succeeding with lake management. National environmental agencies, such as the Nature Conservation agency, are providing advice, some funding and as possible also monitoring. Regional lake governance is partially developed and flood management is more developed due to this issue being of more socio-economic value. However, needs for necessary final lake governance system design and development in Latvia shall be constantly stressed, particularly, looking towards cross-level and cross-sectorial integration framework establishment (Konkovs, Ernsteins, 2021).

Many European countries have well developed lake governance studies, also management process discussion (Bréthaut, 2014; Blenckner, 2009; Bitterman, 2020), as well as, governance approaches and models development, and application (Kooiman, 2008). Also, there could be seen more involvement of NGO's, including ones that focus on specific lakes, such as the Lake Constance foundation in Austria (Lake Constance Foundation, 2020), and, in general, municipalities in many European countries are much larger and have more capacities and resources, including more overall public communication and particular information regarding lake governance environmental issues and nature. In Latvia, research on lake management in general as well as the development of lake management guidelines was carried out during last decade and more actively starting from last seven year planning period 2014-2020. These guidelines were developed to enable local governments to coordinate their lake and river management work, provide a basis for the development of lake and river management plans, and have a common water management methodology (Urtans, 2012; Veidmane, 2020). Lastly, also in-depth studies, taking into account both environmental and economic issues in lake management, governance approaches and legislation improvement issues were commissioned (Veidmane, 2020), but, in general, there are missing studies on lake governance and administration.

\section{Research approach and case study research methodology}

The goal of this research was to study the municipal level lake management practice developments, applying general research-and-development (R\&D) framework approach and researching particularly the 
status and development trends of the three governance's dimensions' employment - governance content by socio-ecological system (SES) approach, governance segments as for main stakeholders' involvement and participation, as well as, the set of governance instruments, especially, institutional/administrative ones. Particularly, study was designed around the lake governance instruments framework consisting of six, necessary complementary, types of instruments meant to be the mandatory bases for establishing and functioning of necessary governance system (Ernsteins, 2017a; Konkovs, Ernsteins, 2020), performing analysis of the instruments available for the lake governance at the various administrative levels in Latvia - policy and legislation instruments, planning, institutional and administrative, economic and financial, infrastructure and technology, and also communication and collaboration instruments. Besides this instrumental dimension, there were started to study also the other two governance process dimensions governance content dimension, being based on a socio-ecological systems (SES) approach and governance stakeholders dimension (Ernsteins, 2017ab). Latter is to be mandatorily framed and represented by following five governance segments as governmental and corporate segments, societal/household and municipal segments, as well as, instantly growing mediator segment, including media and NGO's but also formal/non-formal education and science-technology sectors, being so crucial for communication instruments development and implementation.

There were chosen pilot municipalities, having diverse and successful lake management approaches utilised, and, for the first study stage, document analysis and semi-structured interviews with related municipal specialists were done, using case study research (CSR) methodology application, also in the future offering guidelines for the development of municipal lake management. Within the framework of the pilot study, the assessment of water resources/lakes management instruments in Vidzeme planning region in general, and, in practice, in Burtnieki, Madona, Vecpiebalga, Limbazi and Aluksne municipalities, as well as, for complementary approach there were chosen Liepaja city municipality case in Kurzeme planning region, having also rich experience in coastal research and coastal integrated management, as definitively the case to be studied and as much as possibly transformed to inland waterbodies governance applications (Ernsteins, 2017b).

Within the framework of the research, altogether the employees of the eight municipalities - Aluksne, Burtnieki, Madona, Vecpiebalga, Liepaja and also Jurmala, Carnikava and Daugavpils - were interviewed on the municipal organisations involvement in the lake management, especially, on the three lake governance dimensions - governance content, instruments and target groups. At least two water/lake (environmental) management related key persons in each municipality were interviewed (in total 13 semi-structured interviews) and all municipal frame of legislative-planning documentation were studied in six municipalities (Aluksne, Vecpiebalga, Burtnieki, Liepaja, Madona, Limbazi) as for case study research. There were interviewed - municipal environmental/natural resources specialists and some existing lake management specialists, municipal executive directors, public relations specialists, chairmen and employees of lake NGOs, chairmen of lake and water management agencies, utilities departments managers. While in the case of Carnikava, Jurmala and Daugavpils municipalities, 4 semi-structured interviews were conducted.

\section{Municipal case studies research: lake management approaches}

In the studied municipalities, the executors of the municipal lake administration differ between the municipalities - in some cases, the administration is performed by municipal companies, in others by municipal regular territorial administrative structures, while in Madona the implementation is performed by NGOs, but in Limbazi we see mixt or combined management option. The part of communication instruments 
is insufficiently developed and unused in the studied municipalities - information on the lakes and their management is difficult to access for the residents. Education in this respect is also insufficiently developed yet even growing recently. A similar problem exists at the national level: information on lakes and their management is limited and insufficient, and dissemination opportunities have been little studied or used. National legislation also does not specify which organisation is the executor of river basin plans (including lake management) at the national level. Municipalities are currently fully responsible for their lakes, but they have sufficient resources for only part of the lakes, and private lakes are not under their direct control. The studied municipalities had the following lake performance and we have recognized 5 lake management approaches as studied in chosen municipalities, being described separately in the next chapters.

\subsection{Utilities management sector approach.}

In the Utilities management sector approach case lake management is performed by municipal utilities/service departments and municipal territorial management structures as a part of the municipality's overall territory management. This is the most common form in Latvia, but municipalities more and more are adopting other, more specialised forms in the country.

\section{Vecpiebalga rural municipality}

The area of the municipality is $542.2 \mathrm{~km}^{2}$, of which the waters cover $27.2 \mathrm{~km}^{2}$, having seven public lakes in the municipality, the largest of which is Lake Alauksta and in 2020 around only 4000 inhabitants lived in the municipality, spread across five local administrative units exist in the municipality. The municipality has a wavy, uneven terrain, as well as about half of the territory is covered by forests and tourism sector is very important for the municipality, as it has limited other types of resources, but tourism is seasonal, limiting its development opportunities.

In Vecpiebalga municipality, lakes are managed by the Utility division of the municipality and subdivisions of its administrative units. In 2016, regulations for the use of public lakes were commissioned and developed for Vecpiebalga municipality, as well as the municipality has strict regulations related to the protection of the landscape of the municipality. The management of the municipality's lakes and water resources is rather integrated into its general development plans, as it is part of its landscape protection and is important for its economic development, so also subsequently, even very limited, funded by municipal budget. The municipality has a decentralised water supply and treatment infrastructure and a very well-developed swimming infrastructure near Alauksts and Inesa lakes, which also includes playgrounds and drinking water taps. The municipality publishes information about the lakes on its website, including in connection with their management, but much of this information is related to the tourism sector. Residents of the municipality are involved in the public discussion of the management of lakes, water and the natural environment, as well as in the case of Lake Alauksta the voluntary fishing inspectors are involved. The management of lakes and water resources is not separated from the overall environmental and territorial management. The management of lakes and water resources is integrated into the socio-economic sector of the municipality and the municipality's main target groups are local residents, tourists, anglers, holidaymakers and farmers, in whose interests the water management is performed and who are also involved in the management of the sector itself.

\subsection{Environmental management sector approach}

In the environmental sector management approach, lakes are managed by special environmental/nature resources management institutional structures or departments in the municipality or by commissioned 
separate environmental/natural resources specialists. These structures may be part of other municipal departments, such as the utilities department. An example of is Carnikava and Burtnieki municipalities.

\section{Burtnieku rural municipality}

The municipality consists of six territorial units and the area of the municipality is $702.6 \mathrm{~km}^{2}$, of which $50.4 \mathrm{~km}^{2}$ is water - in 2020 around 8000 inhabitants lived in the municipality and the population density is 11.3 inhabitants / $\mathrm{km}^{2}$. The largest lake in the region is Lake Burtnieki, one of the largest lakes in Latvia. The municipality's tourism sector is an important funding source, but most tourists come to the municipality seasonally.

In Burtnieki municipality, the lake and water resources are managed by the Utilities department having specialized and specially commissioned natural resources specialist. Burtnieki municipality has also special regulatory provisions regarding water management and the connection procedure of the municipality's decentralised water supply system, and procedure requirements of fishing, crayfish, and underwater hunting in the municipality's lakes, especially in Lake Burtnieki. Sustainable use and management of water resources, especially with regard to the management of Lake Burtnieki, is integrated into the development planning documents of Burtnieki municipality and the spatial plans. There is also special the Lake Burtnieki Council in municipality, which receives funds from the municipality's environmental budget and the municipality's territory and housing management budget, as water resources management is integrated into the municipality's overall economic management. Burtnieki municipality manages the municipality's hydro-technical infrastructure, including the decentralised water supply and treatment system, as well as has created a diverse, well-maintained swimming infrastructure at the most frequently visited lakes in the municipality. The website of Burtnieki municipality contains various information about water resources, including their management, as well as the municipality provides educational materials for schools, environmental education programs, as well as, has a free monthly publication, "Burtnieki News", which frequently also publishes information about lakes and rivers. Municipality involves local population in the management of its lakes and water resources, as it cooperates with fishermen's and hunters' associations, as well as lake management issues related to Lake Burtnieki are regularly submitted for public discussion. Burtnieki municipality also integrates other nature protection sectors in the management of lakes and water resources, as it is located in the territory of the North Vidzeme Biosphere Reserve and the natural environment sector as common management. For Burtnieki municipality, the water sector is integrated into the socio-economic sphere, as it is managed by the municipality's economic structures and the management of the water sector is important for its economy and culture, which is closely connected with Lake Burtnieki. The Burtnieki Municipality Lakes and Water Resources department's main target groups are the local residents and anglers of the municipality, who are involved in the Burtnieki Lake association and whose interests the municipality performs the water sector management.

\subsection{Water Management Sector Approach}

In the water management sector approach, municipalities have set up special divisions/corporations/agencies to manage their lakes and public waters. These organisations receive their funding mostly from the municipality, in addition to other forms of support. An example of such municipalities is Aluksne, where such functions are performed by the municipal agency "ALJA". In Latvia, this is yet a very rare form of lake management, but Limbazi, Usma and other municipalities are currently setting up their own agencies following the example of Aluksne.

\section{Aluksne rural municipality}


In 2020 around 14000 inhabitants lived in the municipality, with territory of the municipality covering $1697.6 \mathrm{~km}^{2}$ - the population density is 8.4 inhabitants / $\mathrm{km}^{2}$. Most of the territory is covered by distinctly hilly terrain and by the type of land use, $57.1 \%$ is occupied by forests, $29.3 \%$ by agricultural land, $3.8 \%$ by bogs and $9.4 \%$ by other lands. The municipality includes Aluksne city and 15 local administrative units and there are seven public lakes in the municipality, the largest of which is Lake Aluksne within municipality central town. The tourism sector of the municipality is of a seasonal nature, as most visitors come to it in the summer, but it is not particularly important, as other sources provide its profits.

In Aluksne municipality, lake management is performed by a special agency, "ALJA" founded by the municipality, which manages the municipality's all the public lakes and is responsible for all municipality's water resources and their management issues. Aluksne municipality has several water resources planning/management documents, and regulations, including special normative regulations related to public order maintenance at water bodies and their use. The municipality's water resources management is well included in its general development planning, and the municipality has special planning documents regarding water objects and their coastal zones. Aluksne municipality has a special budget for environmental protection and management of municipal territories. The agency "ALJA" is budget financed, and water management of the municipality is performed, being monitored from municipality management too. Agency "ALJA" is also responsible for the management of hydro-technical infrastructure of the municipality; thus, all dams, locks, as well as water supply and treatment system are under the responsibility of this Agency. The main source of information resources related to environmental issues (including water resources) for the residents of Aluksne municipality is the municipality home page, where the municipality planning documents and related regulations can be easily found, and in 2019 special "nature information houses" were established in Veclaicene protected landscape area, where residents and visitors can receive various types of information about natural objects, including lakes. Aluksne municipality actively involves local residents by conducting various surveys and public discussions on various issues, including water resources and involving local residents in the development of development plans. In the natural environment content of the Aluksne municipality, water resources are related to other sectors of the natural environment because the territory of the municipality includes part of the protected landscape area and several nature reserves and protected habitats are lakes or lake islands. Lakes and water resources management is also integrated into the municipality's socio-economic environment, as water resources management is important in the municipalities' joint management. Lake Aluksne contains cultural and historical values that the municipality is entrusted to manage and maintain. The main target groups are local residents, tourists, and local entrepreneurs, whose businesses (processing of agricultural and agricultural products) impact water resources or depend on tourists attracted to the lakes (hotels, guest houses and restaurants).

\subsection{NGO management sector approach}

In the NGO sector management approach, the lakes in the municipality are managed by NGOs, which perform most or all of the lake management work. Such NGOs can be established by municipalities (TopDown) as in the case of Liepaja, where the lakes are managed by the municipal association "Liepajas lakes", but there are also NGOs founded by local residents, as in the case of Madona, where lakes are managed by local lake associations, founded in mixed by the local inhabitants/entrepreneurs, supported by municipality and some NGO's incomes, fishing taxes.

\section{Liepaja city municipality}


Liepaja is the third-largest city in Latvia, one of the nine cities of national importance in the country, located on the western shore of Latvia between the Baltic Sea and Lake Liepaja, which is connected to the sea by the Trade Channel. The area of the city is $68.0 \mathrm{~km}^{2}$, of which $16.7 \mathrm{~km}^{2}$ is water. In 2020 , the city had a population of around 70 000. In Liepaja, lakes and water resources are managed by the association "Liepajas lakes", founded by the city of Liepaja and several other municipalities around the lake, coordinated by the city's Environmental health and public participation department, which cooperates with the association on water resources management, especially lakes. Liepaja has strictly binding regulations concerning the management of Lake Liepaja, nearby protected areas and coastal areas. The cities Utility department also manages most of the cities' public areas, including all parks and green territories in the city and the hydro-technical infrastructure. Liepaja city development documents and spatial plan include integrated lake and water resource management and coastal area management as important elements for city development.

The management of lakes and water resources receives funds from the income of the association "Liepajas lakes" from the sale of fishing and layout licenses, financial support of the city to the association, as well as from the environmental budget of the city of Liepaja. The city is responsible for the management of the technical infrastructure (including hydro technics), but the machinery and tools (including the water grass mower) needed for the direct maintenance of the lakes are owned by the association. Residents of the city of Liepaja have access to extensive information about the management of lakes, coasts and protected areas; there are eco-schools and ordinary schools having educational material on these issues, and the city has recently established an environmental education centre on water management. The city promotes public participation in the management of the water and coastal sector through public consultations on the issues of these sectors, clean-up of the territory of coastal and water bodies, as well as listening to the suggestions and opinions of the residents. The city does not separate its water resources from the general natural environment management sector, as they are closely related to the management of protected areas, and Lake Liepaja itself is partially a nature reserve. The city's socio-economic environment depends to some extent on the efficient management of water resources, so the water sector is closely linked to the overall operation and management of the city. The city's main target groups are its inhabitants, anglers and fishermen, as well as tourists and holidaymakers.

\section{Madona rural municipality}

The area of Madona region is $2160.2 \mathrm{~km}^{2}$ and in 2020, the population of the municipality was around 22 000. Lake Lubana is located partially in the region, which is the largest lake in Latvia. There is a total of 26 public lakes in the municipality. Tourism is an important source of resources in the municipality, but it is not the only one, and tourism in the municipality is seasonal, which hinders its development. In Madona municipality, lakes are managed by a number of local territorial communities' development NGOs and two lake management associations, including the Kala Lake Council, which was by local residents founded, and the municipality itself performs mainly support functions. The municipality sets strict quotas and restrictions for fishing in the lakes of the municipality and has binding regulations regarding the use of the lakes. Lake and water resources management is also integrated into the municipality's development programs and plans, as part of Lake Lubana is located in the municipality and protected landscape areas. The municipality lake management receives funding from three sources - the municipality territory, housing and environmental protection budget, NGO profits from the sale of fishing and angling licenses, and municipal income from the rental of fishing gear, which is invested back into the lake management. Madona's hydrotechnical and lake management infrastructure is divided between the municipality and NGOs - the municipality manages all technical, including hydro-technical infrastructure, while NGOs manage special 
lake infrastructure, including swimming infrastructure. The communication issues of the lakes of the municipality are solved by NGOs, of which the "Kala Lake Council" has special educational programs related to the lakes. In Madona municipality, issues of public participation are addressed by NGOs, but the municipality also organises public consultations on environmental issues, including the management of protected areas and lakes and related plans. The management of the Madona region's natural environment does not distinguish the management of lakes and water resources from other sectors because environmental management is considered a unified system. In Madona municipality, water resources management is integrated into socio-economic management because the environmental management of the municipality, especially with regard to water resources, is closely related to its economic activities, the income of which is provided by tourism, agriculture, recreation and fishing, as well as their provision. The main target groups for the management of Lake Madona are locals, entrepreneurs, anglers and fishermen.

\subsection{Cross-sector management complex approach}

The Cross-sector management complex approach is a combination of several sector management approaches or even all above mentioned four sectoral approaches of management. Usually, they are Utility structures in combination with local government or NGOs founded by residents.

\section{Limbazi rural municipality}

Limbazi municipality is the clearest example because of having all of the previous forms of management operated in this municipality. There is a lake management agency ALDA, lake NGOs, municipal departments and Utilities department and municipal territorial units involved. The municipal lake management agency manages the three largest lakes in the municipality, while the other lakes are managed by local NGOs or municipal territory administrative units. Limbazi has 4 NGOs that manage lakes established by the local inhabitants and landowners. Limbazi is also the only municipality in Latvia, who has Blue Flag swimming area for lake. Limbazi municipality is a municipality in the north-west of Vidzeme, which combines the city of Limbazi with 7 administrative units, haing an area of $1171.2 \mathrm{~km}^{2}$, of which $34.4 \mathrm{~km}^{2}$ is water. In 2020 , around 17000 inhabitants lived in the municipality. There are eight public lakes in the municipality. Tourism is an important source of additional funds for the municipality, but it is not the main one because the municipality has well-developed agriculture and industry, including one of the largest dairy companies in Latvia.

In Limbazi municipality, lake management is performed by three types of organizations - the lake management agency "ALDA" founded by the municipality, which is responsible for the management of the three largest lakes, local government institutions responsible for lake and water management in their territory, and 4 NGOs that manage three lakes and one a series of lakes in the municipality. The municipal Utilities and Planning departments are involved in managing the lakes as well. Limbazi municipality has binding regulations regarding fishing, angling, the use of swimming areas, the use of motorized water transport (excluding electric motors) is prohibited, as well as strict regulations regarding public behavior in public recreation areas. The municipality lake management agency ALDA has regulations, which determine its responsibilities, as well as each managed lake or group of lakes has management plans, as well as special planning documents regarding fishing. Limbazi municipality maintains ALDA with its own budget, as well as the agency and NGOs make a profit from issuing fishing licenses and providing other services related to water or coastal recreation.

The infrastructure of swimming places is at the largest lakes, as well as in all public swimming places. Water treatment and transmission systems are under the control of the municipality itself, as well as special hydrotechnical infrastructure. The agency and associations manage recreational infrastructure by the lakes, 
including boat docks. For the residents of the municipality, information about the lakes is available on its website, social portals, as well as in the municipality newspaper. There are environmental education programs provided by both the Blue Flag program, Ecoschools and the municipality itself. The municipality does not have special advisory councils, but their lack is compensated by the large number of NGOs in which residents living near the lakes work.

Other environmental and nature protection sectors are integrated with regard to water, coastal and recreation management. Not all sectors are integrated, but those related to direct lake management are. Socio-economic sectors are integrated into the lake management, as the provision of recreation and recreational facilities by the lakes is important for both the municipality and the local population. The main target groups of Limbazi lakes are locals, holidaymakers, tourists, anglers, fishermen, the municipality, as well as young people (regarding environmental education).

There relevant interesting examples of lake governance planning in few other municipalities.

Carnikava rural municipality - the municipality's total area is 80.2 square kilometres, which is the third smallest municipality in Latvia; moreover, most of it is covered by forests, but a quarter of the total area is used for agriculture. Carnikava is known for its nature park "Seaside", which is included in the European Union's network of specially protected areas "Natura 2000". In 2020, the municipality had a population of around 9 000. For the region, tourism is important, but it creates difficulties for local residents who live near lakes, so the municipality does not want to develop tourism too much. In Carnikava municipality, lakes are managed by the Environmental division of the Utilities department, as well as the municipal Planning department has its own environmental specialists. Carnikava has a number of binding rules on behaviour in public places, coastal management and other areas, but the most important are Binding regulations of Carnikava district council On the Procedure for Using the Public Waters in the Administrative Territory of Carnikava Region and Their Shores. These include the management of all public waters in the municipality.

Daugavpils rural municipality - there are 19 administrative units in the Daugavpils municipality. In 2020, the population of the region was around 20000 . It covers an area of $1876.1 \mathrm{~km}^{2}$, of which $82.2 \mathrm{~km}^{2}$ is water. The municipality includes part of the Daugava River and has five public lakes. The tourism sector is important to the region, but it has many other sources of funding, including a welldeveloped agricultural sector, which reduces the need to focus on tourism. Daugavpils municipality lakes are managed by the Environmental department of the Economic division of the municipality. The largest lake management works are carried out by the municipality, while smaller works, such as the creation of swimming areas, are carried out by each local administrative unit. The municipality has rare specific - an Environmental Management Specialist in Lake Management, part of its Natural Resources Division.

Jurmala city municipality is the largest resort town in Latvia, about 25 kilometres west of capital city Riga. The city covers an area of $100 \mathrm{~km}^{2}$ and stretches for $24 \mathrm{~km}$ along the Gulf of Riga and having meandering Lielupe river from other side. The population was around 50000 in 2020. The municipality does not have its own lakes, but it has a coastal governance practice, and the Kemeri National Park is nearby. Tourism in Jurmala is the main source of funds, but it is seasonal in nature, and outside the tourist season, the city has difficulties with resources. For the city of Jurmala, the waters and coast are managed by the city Development and environmental issues committee and the municipalities Utilities department manages all hydro-technical infrastructure. Other commissions are also involved in coastal and the city's water infrastructure management. The city has various binding regulations regarding public behaviour in public areas, swimming areas and on the coast. The city has strict national regulations regarding 
construction in the dune area. The city of Jurmala has a special Action plan for the protection of water resources of Jurmala city (2016).

\section{Discussion and conclusions}

In Latvia, the lake governance system is developing - there are basic instruments, but all kinds of resources, including human resources and institutional capacity are insufficient, and, legislation need to be further specified, particularly, the surface waterbodies management enforcement. In Latvia, there is an insufficient communication system for lake management - mediators are not sufficiently involved, and the information is also mainly intended for tourists, and this group of instruments is insufficiently researched and developed. There is recognizable necessity of further but system-based comprehensive improvement of the lake governance, in particularly, the system of the lake governance instruments at the national level and various support mechanisms and framework governance to pro-actively contribute to local level lake governance. Three complementary governance dimensions' employment towards coordinated multiactor, multi-instrumental, multi-sectorial thematical applications would be seen as necessary potential for the further establishment of the local and national lake governance system.

The capacity of local governments, especially rural counties, is not sufficient, but after 2021 administrative-territorial reform the combined, aggregated municipalities will have more capacities. All studied municipalities in the first R\&D stage possess certain lake management developments, what also needs to be studied further in particular. The study of all three governance dimensions showed, that there is still limited understanding and approach towards SES approach utilisation. Potential of main local stakeholder's involvement and pro-active self-participation has been not yet understood and targetoriented. There are wide range of governance instruments available in studied municipalities, also new water/lake management targeted planning documents, but lake communication instruments (information, education/training, participation and lake-friendly behaviour) are mostly underdeveloped. There could be done also further conclusions on administrative-institutional governance instruments, surveyed in particular.

5) There are five different approaches (models) of municipal lake management identified, which have their own local history, characteristics and operating instruments with their combinations, compare to the any single model/system: Utilities management sector approach; Environmental management sector approach; Lake management sector approach; NGO management sector approach and also Complex (cross-sector) management approach using several of the previous approaches at once. There is not realistic to develop one standard approach of lake management, since municipal management conditions are very diverse in the size, location, number of population, existent administration traditions, and, subsequently, the capacities and resources available to particular municipalities, as well as, the availability and number, size and multiple use of lakes. Basically, lakes as any other municipal territories are managed by usually scarce municipal territory administrative units and also Utilities departments/services, responsible for standard communal services (water/wastewater, waste, heating and territorial clean-up), but various combined (cross-sector) approaches to lake management are becoming more widespread, and various types of NGOs are increasingly involved in such work.

6) Municipal agencies and also by municipality established NGO could be seen as the most successful forms of lake management, as they have clearly defined functions, responsibilities and more or less efficient specialized organization. Agencies possess also a range of governance instruments, partnership 
interests/tasks and more open SES understanding and application approach - it would be desirable to develop this experience further and process of this experience dissemination has already started as neighbour and further afield municipalities are studying experience of those few lake management agencies. Also complex (cross-sector) management approach for the lake management appears more and more often in the lake management sector in Latvia, being promoted by the limited municipal capacities, especially, having many, diverse and distantly spread lakes in the municipality, but also initiatives of local residents or already existent NGO's, and, some other factors, including the presence of nature protected areas / objects.

7) The national environmental/water sector governance is not yet in the position to offer to municipalities any specific lake management models and cannot sufficiently support by various necessary governance instruments (besides recently growing funding for lake management planning) the municipal lake management. As a result of administrative-territorial reform taking place in 2021, 42 out of 119 municipalities will be formed, which will have significantly more resources and eventual staff required for environmental/lake management, but it might also promote the spread of complex approach of lake management by merging combined municipalities with already existent different approaches of lake management and due to its eventual efficiency and complementary and participatory character. In order to maximize the management efficiency of lakes and all water resources, the crosslevel networking governance system with both top-down and bottom-up approaches used/combined would be required and possible.

\section{Acknowlegements}

The University of Latvia supported this paper publication and authors acknowledge the contribution of the lake specialists and employees of all the studied municipalities.

\section{Bibliography}

1. Bréthaut C., Clarvis M.H. (2014) Interdisciplinary Approaches for Analysing Management Challenges Across the Rhône Basin. Regional Environmental Change, vol. 15, no. 3, pp. 499-503.

2. Blenckner T., et.al. The Impact of Climate Change on Lakes in Northern Europe, pp. 339-358, 2009.

3. Bitterman P., Koliba C. (2020). Modelling Alternative Collaborative Management Network Designs: Agent-Based Model of Water Management of Lake Champlain Basin. Journal of Public Administration Research Theory, vol. 30, no. 4, pp. 636-655.

4. Ernsteins R., Kudrenickis I., Kaulinš J., Lontone-Ievina A. (2017a). Pro-Environmental Municipal Governance Developments in Latvia: Sustainability and Integration Principles in Practice. Proceedings of the International Scientific Conference, VGTU, Vilnius, Lithuania, May 2017, 308-317 pp.

5. Ernsteins R., Lontone - Ievina A., Lagzdina E., Osniece K., Kaulins J. (2017b). Integrated Coastal Management Practice Case Studies: Deficiency of Collaboration Communication and Socio-ecological System Approaches. International conference proceedings, Jelgava, Latvia, April 2017, Issue 45, pp. 63-70.

6. Kooiman J, Bavinck M, Chuenpagdee R., et al. (2008). Interactive Management and Governability: An Introduction. The Journal of Transdisciplinary Environmental Studies, Vol. 7, pp. 2-11.

7. Konkovs K.A., Ernsteins R. (2020). Lake Governance System Development in Latvia: Towards Cross-Level and Cross-Sectorial Integration Framework. Proceedings, 20th International Multidisciplinary Scientific GeoConference, SGEM, December 2020, Vienna, Austria, Vol. 20 (1.3), 179-192 pp.

8. Lake Constance Foundation. (2020). Lake Constance: Experience and Lessons Learned, Brief. Global nature.net. pp. 1-14, 2020.

9. Schewe R., Hoffman D., Witt J., et al. (2020). Citizen-Science and Participatory Research as a Means to Improve Stakeholder Engagement in Resource Management. Environmental Management. pp. 1-14.

10. Stokmane, M. (2019). Coastal Management Report in Jurmala Municipality ("Jurmala PPP"). The University of Latvia, Faculty of Geography and Earth Sciences. Riga.

11.Truksans, D., Biezina, L., Graudina-Bombiza, S., Zilniece, I., Ernsteins, R. (2020). Municipal pro-environmental governance revitalisation: Expanding blue and green flag complementing instruments. Proceedings, International GeoConference, SGEM, Albena, Bulgaria, August 2020, 5.1, pp. 545-560.

12. Urtane L., Urtans A. V., Ceburaskins M. (2012). Guidelines for Planning the Use and Management of Water Bodies and Watercourses (in Latvian). Vidzeme Planning Region, Valmiera, Latvia, 210.p. 
Proceedings of the 2021 International Conference "ECONOMIC SCIENCE FOR RURAL DEVELOPMENT" Jelgava, LLU

ESAF, 11-14 May 2021, pp. 139-150 DOI: $10.22616 / E S R D .2021 .55 .014$

13. Veidemane K. (2020). Recommendations for efficient river management in Latvia (In Latvian). Baltic Environmental Forum, Riga, Latvia. p.26.

14. Zacharias, I., Liakou, P.; Biliani, I. (2020). A Review of the Status of Surface European Waters Twenty Years after WFD Introduction. Environmental Processes, vol. 7, No. 4, pp. 1023-1039. 